\title{
Impact of upper Wardha canal irrigation project on economy of farmers
}

\section{A.V. CHOUDHARI AND S.M. SARAP}

Article Chronicle :

Received:

30.12.2015;

Revised :

20.04.2016;

Accepted :

01.05.2016

Key Words :

Cost, Economics, NB, B, Returns
ABSTRACT : The present study entitled, "Impact of Upper Wardha canal irrigation project on the economy of farmers." The study has been undertaken in Amravati district of Vidarbha region. Primary data was collected from Tiwsa tahsil and ten villages are selected purposely, from each village of 40 beneficiary farmers were selected for present study. The selected farmers were classified into three category viz., small, medium and large according to their land holding. The average marketing cost for small, medium and large sized groups was Rs. 77.00 , Rs. 73.00 and Rs.69.00 per quintal. The maximum cost required in marketing was for packaging which accounts for Rs. 22.00 , Rs.21.00 and Rs. 20.00 per quintal for small, medium and large size groups, respectively. The value addition in processing of dal mills showed that per quintal Rs.1132.68, Rs.1245.90 and Rs.1250.89 for small, medium and large size groups of dal mills, respectively. The standard cost concept fixed cost, variable cost, total cost, marketing cost, net returns and value addition was used for the analysis of data.

HOW TO CITE THIS ARTICLE : Choudhari, A.V. and Sarap, S.M. (2016). Impact of upper Wardha canal irrigation project on economy of farmers. Asian J. Environ. Sci.,11(1): 34-39, DOI: 10.15740/HAS/AJES/11.1/ 34-39.

Author for correspondence :

\section{A.V. CHOUDHARI}

Shri Shivaji Agriculture

College, AMRAVATI (M.S.)

INDIA

Email : ankushac588@

gmail.com

See end of the article for

Coopted authors' 